Supporting Information for

\title{
Electrocatalytic reduction of low concentration $\mathrm{CO}_{2}$ gas in a membrane electrode assembly electrolyzer
}

Dongjin Kim ${ }^{a, b}$, Woong Choi ${ }^{a}$,Hee Won Lee $e^{a, c}$, Si Young Lee $e^{d, e}, Y_{\text {ongjun Choi }}^{a, c}$, Dong Ki Lee $e^{a, c, f}$, Woong Kim ${ }^{b}$, Jonggeol Na ${ }^{g}$, Ung Lee $e^{a, c, f *}$, Yun Jeong Hwang ${ }^{d, e *}$, and Da Hye Won ${ }^{a, c *}$

${ }^{\mathrm{a} C l e a n}$ energy research center, Korea Institute of Science and Technology, Seoul 02792,

Republic of Korea

${ }^{\mathrm{b}}$ Department of Materials Science and Engineering, Korea University, Seoul 02841, Republic of Korea

${ }^{\mathrm{c}}$ Division of Energy and Environmental Technology, KIST School, Korea University of Science and Technology (UST), Seoul 02792, Republic of Korea

${ }^{\mathrm{d} D e p a r t m e n t ~ o f ~ C h e m i s t r y, ~ S e o u l ~ N a t i o n a l ~ U n i v e r s i t y, ~ S e o u l ~ 08826, ~ R e p u b l i c ~ o f ~ K o r e a ~}$

${ }^{\mathrm{e}}$ Center for Nanoparticle Research, Institute for Basic Science (IBS), Seoul 08826, Republic of

Korea

${ }^{\mathrm{f}}$ Graduate School of Energy and Environment (Green School), Korea University, Seoul 02841, Republic of Korea

gDepartment of Chemical Engineering and Materials Science, Graduate Program in System Health Science and Engineering, Ewha Womans University, Seoul 03760, Republic of Korea

\section{Corresponding Author}

Ung Lee - E-mail: ulee@kist.re.kr, Yun Jeong Hwang - E-mail: yjhwang1@snu.ac.kr, Da Hye Won - E-mail: dahye0803@kist.re.kr 


\section{Table of contents}

\section{Supplementary Notes}

\section{Experimental Section}

1. Synthesis of Ni-N/C

2. Characterizations of the catalysts

3. Electrochemical measurement

4. Computational fluid dynamics simulation

\section{Supplementary Figures}

Figure S1-S15

\section{$\underline{\text { Supplementary Table }}$}

Table S1

Supplementary references 


\section{Supplementary Notes}

\section{Experimental Section}

\section{Synthesis of $\mathrm{Ni}-\mathrm{N} / \mathrm{C}$}

Ni-N/C was prepared by modifying the reported two previous methods ${ }^{1,2}$. To prepare the NiN/C catalyst, ZIF-8 was first prepared ${ }^{1} ; 2.933$ g of zinc nitrate hexahydrate $\left(\mathrm{Zn}\left(\mathrm{NO}_{3}\right)_{2} \cdot 6 \mathrm{H}_{2} \mathrm{O}\right.$, $>99.0 \%$, Sigma-Aldrich) and 6.489 g of 2-methylimidazole (99\%, Sigma-Aldrich) were separately dissolved in $200 \mathrm{~mL}$ of methanol (99.5\%, Samchun Chemicals). Each precursor was dispersed with magnetic stirring for $30 \mathrm{~min}$ and then rapidly mixed in a single bottle. The solution mixture was continuously stirred at room temperature for $24 \mathrm{~h}$. White ZIF-8 product was collected by filtration, washed with methanol, and dried in a vacuum at $60^{\circ} \mathrm{C}$ overnight. $100 \mathrm{mg} \mathrm{ZIF}-8$ was sonicated in $10 \mathrm{~mL}$ of $\mathrm{n}$-hexane (95\%, Samchun Chemicals) for $30 \mathrm{~min}$. After ZIF-8 was well dispersed, $50 \mu \mathrm{L}$ of $1 \mathrm{M}$ nickel nitrate aqueous solution $\left(\mathrm{Ni}\left(\mathrm{NO}_{3}\right)_{2} \cdot 6 \mathrm{H}_{2} \mathrm{O}\right.$, certified crystalline, Fisher-Chemical) was slowly injected into the ZIF-8 solution under ultra-sonication. Next, the mixture was vigorously stirred for $3 \mathrm{~h}$ at room temperature. The mildly green solid was separated by centrifugation at $8000 \mathrm{rpm}$ for $15 \mathrm{~min}$ and dried in a vacuum oven at $60{ }^{\circ} \mathrm{C}$ for $6 \mathrm{~h}$. The Nisubstituted ZIF-8 powder was placed in a tube furnace and heated to $1000^{\circ} \mathrm{C}$ at a heating rate of $5{ }^{\circ} \mathrm{C} \mathrm{min}^{-1}$ for $2 \mathrm{~h}$ under an $\mathrm{Ar}$ atmosphere $\left(100 \mathrm{~mL} \mathrm{~min}^{-1}\right)$ to yield the $\mathrm{Ni}-\mathrm{N} / \mathrm{C}$ catalyst. N/C was prepared by skipping a nickel substitution process in $\mathrm{Ni}-\mathrm{N} / \mathrm{C}$, which is required for $\mathrm{Ni}$ insertion into Ni-N/C precursors.

\section{Characterizations of the catalysts}

Various physical characterizations of the Ag nanoparticles and Ni-N/C catalysts were verified such as structure, morphology, and chemical state. SEM images were obtained using Inspect F50 
at an accelerating voltage of $10 \mathrm{kV}$. TEM and HAADF-STEM images were obtained using a TitanTM 80-300 at an accelerating voltage of $200 \mathrm{kV}$. EDS mapping images were obtained using a Talos F200X instrument. XPS was performed using a Nexsa (Thermo Fisher Scientific) with a monochromated Al-K $\alpha(1486.6 \mathrm{eV})$ source. The X-ray absorption spectrum of the prepared NiN/C for the Ni K-edge spectra was analyzed using a 1D beamline at the Pohang Accelerator Laboratory (PAL). EXAFS and XANES data analyses were conducted using the Athena software. Water contact angle for Ni-N/C and Ag electrodes are analyzed using a contact angle meter (DSA 25 , Kruss) with $2.0 \mu 1$ of DI water.

\section{Electrochemical measurement}

Ag nanoparticles and Ni-N/C electrodes were prepared by spraying the catalysts with an ionic binder onto the carbon paper with a microporous gas diffusion layer (GDL), and both electrodes had the same loading amount (Figure S5). An anion exchange membrane (AEM) was placed between the cathode and anode (i.e., $\mathrm{IrO}_{2}$ on platinized Ti mesh used for facile oxygen evolution reactions) with a zero-gap.

All electrodes for $\mathrm{CO}_{2}$ conversion in a membrane electrode assembly (MEA) electrolyzer were prepared by spraying catalyst ink onto carbon paper (Sigracet $39 \mathrm{BB}$, active area $5 \mathrm{~cm}^{2}$ ). For the $\mathrm{Ni}-\mathrm{N} / \mathrm{C}$ electrode, $6 \mathrm{mg}$ of Ni-N/C was dispersed in $1 \mathrm{~mL}$ of 2-propanol $(99.8 \%$, Samchun Chemicals) with $8 \mu \mathrm{L}$ of Nafion 117 solution (5 wt.\% in a mixture of lower aliphatic alcohol, Sigma-Aldrich) and sonicated for $30 \mathrm{~min}$. The same solution recipe and procedure are used to prepare the N/C electrode. This catalyst ink was sprayed on carbon paper using an air brush with a same loading amount of $1 \mathrm{mg} \mathrm{cm}^{-2}$. The Ag nanoparticles (99.99\% APS 20-40 nm, Alfa Aesar) electrode was prepared by a similar spraying process, but the ratio of the ink solution was different. 
This solution consisted of $30 \mathrm{mg}$ of Ag, $32 \mu \mathrm{L}$ of Nafion solution, and $1 \mathrm{~mL}$ of 2-propanol. Iridium (IV) oxide ( $\mathrm{IrO}_{2}, 99.9 \%$, Alfa Aesar) was used as a catalyst for the oxygen evolution reaction, which is a counter reaction for $\mathrm{CO}_{2}$ reduction. The ink solution, including $30 \mathrm{mg}$ of $\mathrm{IrO}_{2}$ in $1 \mathrm{~mL}$ of 2-propanol with $34.1 \mu \mathrm{L}$ of Nafion solution was sprayed onto the platinized titanium screen mesh (Ti-Pt mesh, 0.002 in, $9 \mathrm{~cm}^{2}$, FuelCellStore) at a loading amount of $1 \mathrm{mg} \mathrm{cm}^{-2}$.

A MEA-type $\mathrm{CO}_{2}$ electrolyzer $\left(5 \mathrm{~cm}^{2}\right.$ scale, Dioxide Materials) was assembled by placing an AEM (Sustanion X37-50 Grade RT, Dioxide Materials) between the cathode (the Ag and Ni-N/C electrodes) and the anode (the $\mathrm{IrO}_{2}$ on Pt-Ti mesh). Various concentrations of the $\mathrm{CO}_{2} / \mathrm{N}_{2}$ mixture gas (that is, $10 \%, 25 \%, 50 \%$, and $100 \%$ of $\mathrm{CO}_{2}$ with $\mathrm{N}_{2}$ balance) were used for applying the various $\mathrm{CO}_{2}$ partial pressure conditions $\left(P_{\mathrm{CO} 2}\right) . \mathrm{CO}_{2}$ gas flow rates $\left(20,50,100\right.$, and $\left.200 \mathrm{~mL} \mathrm{~min}{ }^{-1}\right)$ was controlled using a digital mass flow meter. All gas feeds passed through a gas humidifier (temperature at $30^{\circ} \mathrm{C}$ ) first and then were supplied to the cathode part. At the anode, $0.1 \mathrm{M} \mathrm{KHCO}_{3}$ (95\%, Sigma-Aldrich) electrolyte was circulated by a peristaltic pump. We repeated the electrochemical test at least 3 times to achieve the reproducible data. The activation energy of $\mathrm{CO}_{2}$-to-CO and HER was induced by a gradual increase in the cell temperature controlled by the cell heater and temperature controller by $303,313,323,333$, and $343 \mathrm{~K}$. These results were plotted by linear fitting of the natural logarithm of the partial current densities versus the inverse temperatures based on the Arrhenius equation (Eq.1) to calculate the activation energy:

$$
\ln (i)=\frac{-\mathrm{E}_{a}}{\mathrm{RT}}+\ln (A)
$$

where $i$ is the partial current density for each product, $E_{a}$ is the activation energy, $R$ is the gas constant, $\mathrm{T}$ is the reaction temperature, and $A$ is a pre-exponential factor.

With the MEA configuration, the $\mathrm{CO}_{2}$ conversion performance was examined by chronoamperometry using a potentiostat (VSP, Biologic with booster 20A). Gaseous products 
from the $\mathrm{CO}_{2}$ conversion system were periodically quantified by on-line gas chromatography (GC, 6500GC, Young Lin Instruments Co. Ltd.) with a thermal conductivity detector (TCD). MolSieve 5A (6FT, Agilent) and Hayesep D (11FT, Agilent) packed column was equipped, and ultrapure Ar (99.9999\%) was used as the carrier gas. The products from $\mathrm{CO}_{2}$ conversion were $\mathrm{CO}$ and $\mathrm{H}_{2}$, and the total Faradaic efficiency (FE) was confirmed to be nearly $100 \%$, indicating that there were no liquid products. The $\mathrm{FE}$ of the products (i.e., $\mathrm{H}_{2}$ and $\mathrm{CO}$ ) was calculated by the ratio of each partial current of the products ( $\mathrm{i}_{\mathrm{H} 2}$ or $\mathrm{i}_{\mathrm{co}}$ ) to the total current ( $\left.\mathrm{i}_{\text {total }}\right)$ using the following equation:

$$
F E_{\mathrm{H}_{2} \text { or } \mathrm{CO}}(\%)=\frac{i_{\mathrm{H}_{2} \text { or } C O}}{i_{\text {total }}} \times 100=\frac{V_{\mathrm{H}_{2} \text { or } C O} \times Q \times \frac{2 P_{0} F}{R T}}{i_{\text {total }}} \times 100
$$

where $V_{\mathrm{H} 2}$ and $V_{\mathrm{CO}}$ are the volume concentrations of $\mathrm{H}_{2}$ and $\mathrm{CO}$ analyzed by $\mathrm{GC}, Q$ is the gas flow rate, $F$ is the Faraday constant $\left(96,485 \mathrm{C} \mathrm{mol}^{-1}\right), P_{0}$ is the atmosphere pressure (1.013 bar), $T$ is the temperature (298 K), and $R$ is the ideal gas constant $\left(83.14 \mathrm{~mL} \mathrm{bar} \mathrm{mol}^{-1} \mathrm{~K}^{-1}\right)$.

\section{Computational fluid dynamics simulation}

The computational fluid dynamics (CFD) model was developed based on the electrolyzer

geometry and multiphysics model proposed by Weng et al. ${ }^{3}$ The zero-gap MEA is described using anode/cathode diffusion layer, anode/cathode catalyst layer, and an anion-exchange membrane.

$$
\begin{aligned}
& 2 \mathrm{H}_{2} \mathrm{O} \rightarrow \mathrm{O}_{2}+4 \mathrm{H}^{+}+4 \mathrm{e}^{-} \\
& 4 \mathrm{OH}^{-} \rightarrow \mathrm{O}_{2}+2 \mathrm{H}_{2} \mathrm{O}+4 \mathrm{e}^{-} \\
& 2 \mathrm{H}_{2} \mathrm{O}+2 \mathrm{e}^{-} \rightarrow \mathrm{H}_{2}+2 \mathrm{OH}^{-} \\
& \mathrm{CO}_{2}+\mathrm{H}_{2} \mathrm{O}+2 \mathrm{e}^{-} \rightarrow \mathrm{CO}+2 \mathrm{OH}^{-}(6)
\end{aligned}
$$

Equations (3) to (6) are reactions considered for the multiphysic model. Note that the anodic reactions (OER) and cathodic reactions (HER, $\mathrm{CO}_{2} \mathrm{R}$ ) are describe by equation (3), (4) and (5), (6), 
respectively. The partial current densities of each species (i.e., $\mathrm{H}_{2}$ and $\mathrm{CO}$ ) are calculated by solving charge conservation equations and the Butler-Volmer equations (equation (7)).

$$
\mathrm{i}_{\mathrm{k}}=\mathrm{i}_{\mathrm{o}, \mathrm{k}}\left(\exp \left(\frac{\alpha_{\mathrm{a}, \mathrm{k}} \mathrm{F} \eta_{\mathrm{k}}}{\mathrm{RT}}\right)-\exp \left(\frac{-\alpha_{\mathrm{c}, \mathrm{k}} \mathrm{F} \eta_{\mathrm{k}}}{\mathrm{RT}}\right)\right)
$$

where $\mathbf{i}_{\mathbf{o}, \mathbf{k}}, \boldsymbol{\alpha}_{\mathbf{a}, \mathbf{k}}, \boldsymbol{\alpha}_{\mathbf{c}, \mathbf{k}}$, and $\boldsymbol{\eta}_{\mathbf{k}}$ are represent exchange current density, anodic charge transfer coefficient, and cathodic charge transfer coefficient of species $\mathrm{k}$, respectively.

For the species balance in the porous media, the molar flux and reaction source terms (i.e., charge transfer reactions $\left(\mathbf{R}_{\mathbf{C T}, \mathbf{i}}\right)$, bulk homogeneous reactions $\left(\mathbf{R}_{\mathbf{B}, \mathbf{i}}\right)$, and phase-transfer reactions $\left(\mathbf{R}_{\mathbf{P T}, \mathbf{i}}\right)$ are taken into account.

$$
\begin{aligned}
& \nabla \cdot \mathrm{N}_{\mathrm{i}}=\mathrm{R}_{\mathrm{CT}, \mathrm{i}}+\mathrm{R}_{\mathrm{B}, \mathrm{i}}+\mathrm{R}_{\mathrm{PT}, \mathrm{i}} \\
& \mathrm{N}_{\mathrm{i}}=\frac{1}{\mathrm{M}_{\mathrm{i}}}\left(-\rho_{\mathrm{G}} \mathrm{D}_{\mathrm{i}}^{\mathrm{eff}} \nabla \omega_{\mathrm{i}}-\rho_{\mathrm{G}} \mathrm{D}_{\mathrm{i}}^{\mathrm{eff}} \nabla \omega_{\mathrm{i}} \frac{\nabla \mathrm{M}_{\mathrm{A}}}{\mathrm{M}_{\mathrm{A}}}-\rho_{\mathrm{i}} \mathrm{U}_{\mathrm{G}}\right)
\end{aligned}
$$

$\rho_{G}$ and $U_{G}$ are gas phase average density and velocity and $D_{i}^{\text {eff }}, \omega_{i}, M_{A}$, represent effective diffusion coefficient, mass fraction and molecular weight. In the multiphysics model, the four charged species (i.e., $\mathrm{H}^{+}, \mathrm{HCO}_{3}^{-}, \mathrm{CO}_{3}^{=}$, and $\mathrm{OH}^{-}$) transport through membrane is also considered. The source terms for the charged species are obtained using bulk homogenous reaction.

$$
\begin{aligned}
& \mathrm{CO}_{2}(\mathrm{aq})+\mathrm{H}_{2} \mathrm{O} \leftrightarrow \mathrm{H}^{+}+\mathrm{HCO}_{3}^{-} \\
& \mathrm{HCO}_{3}^{-} \leftrightarrow \mathrm{H}^{+}+\mathrm{CO}_{3}^{=} \\
& \mathrm{CO}_{2}(\mathrm{aq})+\mathrm{OH}^{-} \leftrightarrow \mathrm{HCO}_{3}^{-} \\
& \mathrm{HCO}_{3}^{-}+\mathrm{OH}^{-} \leftrightarrow \mathrm{H}_{2} \mathrm{O}+\mathrm{CO}_{3}^{=} \\
& \mathrm{H}_{2} \mathrm{O} \leftrightarrow \mathrm{H}^{+}+\mathrm{OH}^{-}
\end{aligned}
$$

Lastly, the molar flux of water through membrane occurs via diffusion and electro-osmosis. The diffusion of the water is calculated by using difference of chemical potential and electro-osmosis 
is calculated using Nernst-Einstein equations built in COMSOL. The molar flux of all other charged species is calculated using Nernst-Planck relation described in equation 15 where $c_{i}$ and $\mathrm{z}_{\mathrm{j}}$ are concentration and charge of charged species $\mathrm{j}$. The multiphysic model is constructed using COMSOL Multiphysics and the initial conditions such as species concentration and applied pressure at the catalyst layers are determined in 2-dimensional transport model developed in Ansys Fluent V19.2

$$
N_{j}=-D_{j}^{\text {eff }} \nabla c_{j}-\frac{z_{j} F}{R T} D_{j}^{\text {eff }} c_{j} \nabla \Phi_{L}
$$

The electrolyzer geometry and extrinsic effect are described by using 2-dimensional model developed in this study. The bulk species concentration and pressure at the catalytic layers depending on the anolyte and $\mathrm{CO}_{2}$ gas flow rate are decided using transport model. The mass and momentum conservation in the diffusion layers are described by the Navier-Stokes equation (16) and (17), respectively:

$\frac{\partial \rho}{\partial \mathrm{t}}+\nabla \cdot(\rho \overrightarrow{\mathrm{v}})=0$

$\frac{\partial(\rho \vec{v})}{\partial \mathrm{t}}+\nabla \cdot(\rho \overrightarrow{\mathrm{v}})=-\nabla p+\nabla \cdot(\overline{\bar{\tau}})+\rho \overrightarrow{\mathrm{g}}+\overrightarrow{\mathrm{F}}$

where $\vec{v}$ is the velocity vector, $p$ is the static pressure, $\overline{\bar{\tau}}$ is the stress tensor, $\vec{g}$ is the gravity vector, and $\vec{F}$ is the external body force. The last term of the momentum conservation equation, $\vec{F}$, is used to describe the model-dependent source term. The diffusion layers are composed of carbon paper, so that the momentum loss should be accounted for in this porous media:

$F_{i}=-\left(\frac{\mu}{\alpha} v_{i}+C_{2} \frac{1}{2} \rho v_{m a g} v_{i}\right)$ 
where $F_{i}$ is the ith $(x, y$, or $z)$ component of the source term $(\vec{F})$ in the momentum equation, and $\alpha$ and $\mathrm{C}_{2}$ are the permeability and inertial loss coefficient per unit length, respectively. The permeability of the porous media was directly taken from Weng et al. The first term on the righthand side of Eq. (18) is the viscous loss term described by Darcy's law, and the second term is the inertial loss term. The inertial loss term can be neglected in our system owing to the low flow velocities $\left(<5 \mathrm{~cm} \mathrm{~s}^{-1}\right)$ and laminar characteristics $(\operatorname{Re}<4)$ in the porous media. These source terms are applied only for the GDL regime, and $\overrightarrow{\mathrm{F}}$ was set as $\overrightarrow{0}$ for the flow channel. Note that no reaction source terms are included in 2-dimensional model since no reaction are occurred in diffusion layers. In electrolyzer modeling, abrupt momentum change is expected amongst bodies; thus, numerical instability can be encountered near the interface surface. Therefore, the high orthogonality of the mesh can alleviate the instability issue with a stable convergence of the numerical solution. The number of elements was 63,581 , and the minimum orthogonal quality was 0.149677 , confirming that a high-quality computational domain was generated. The semi-implicit method for pressure-linked equations (SIMPLE) algorithm with a second-order spatial discretization scheme was used for pressure-velocity coupling. The solution dependency on the mesh size ( $\pm 30 \%$ ) was also investigated, and the results showed differences of less than $3 \%$. These mesh-size-independent results confirm that the obtained solutions are numerically robust and accurate. 


\section{Supplementary Figures}

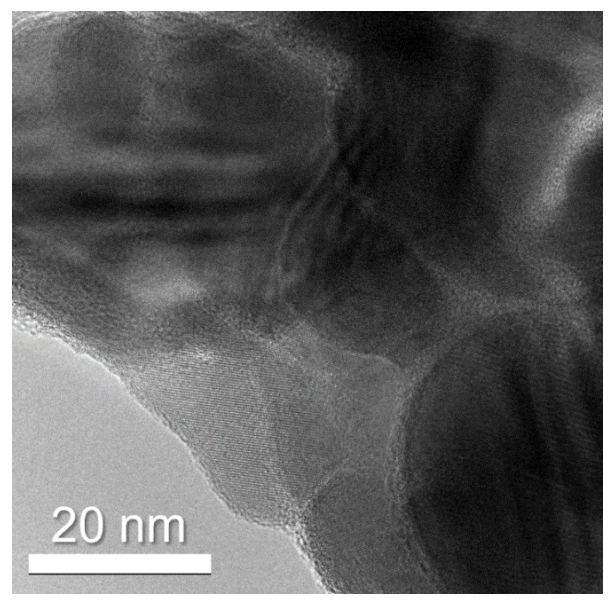

Figure S1. TEM image of the commercial Ag nanoparticles.
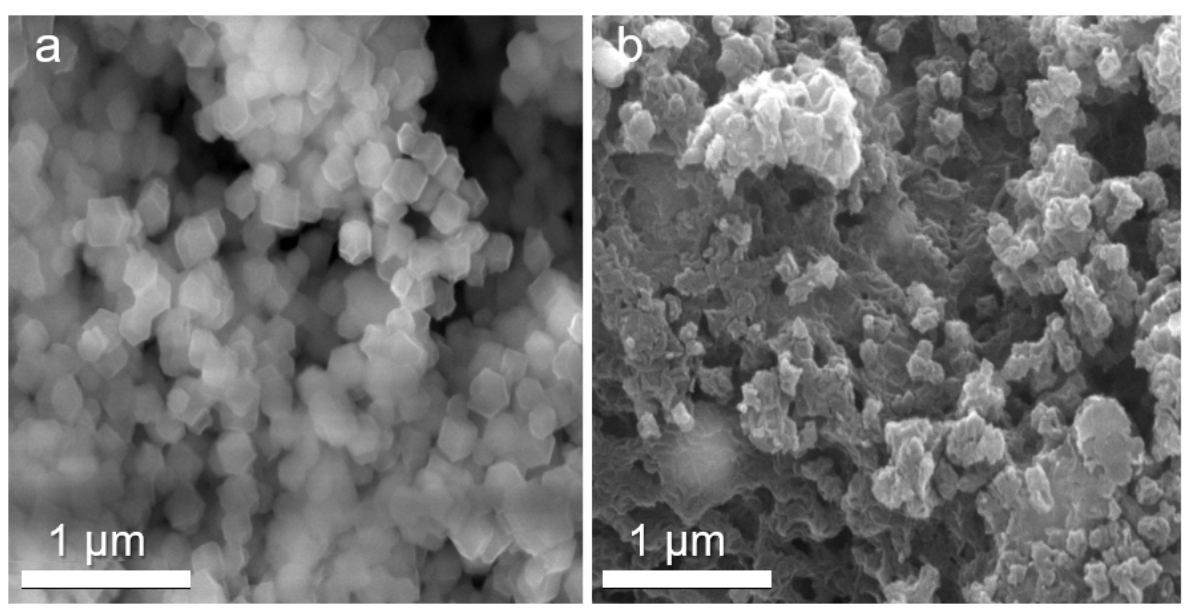

Figure S2. SEM images of (a) as-synthesized ZIF-8 and (b) Ni-N/C. 


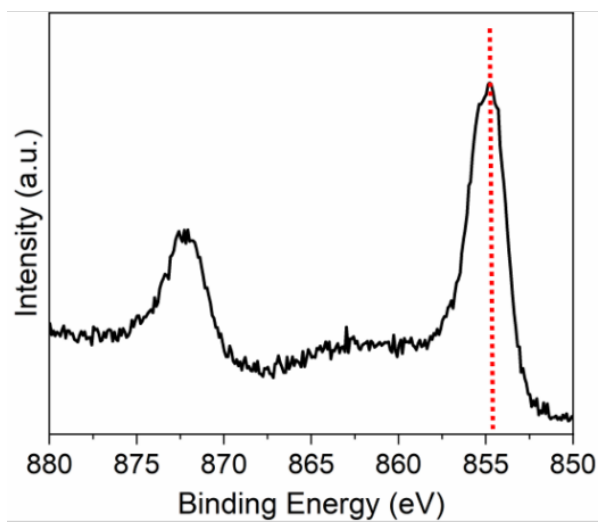

Figure S3. XPS-Ni2p spectrum of the prepared Ni-N/C. Red dot line assigned as $\mathrm{Ni}^{2+}$ state.
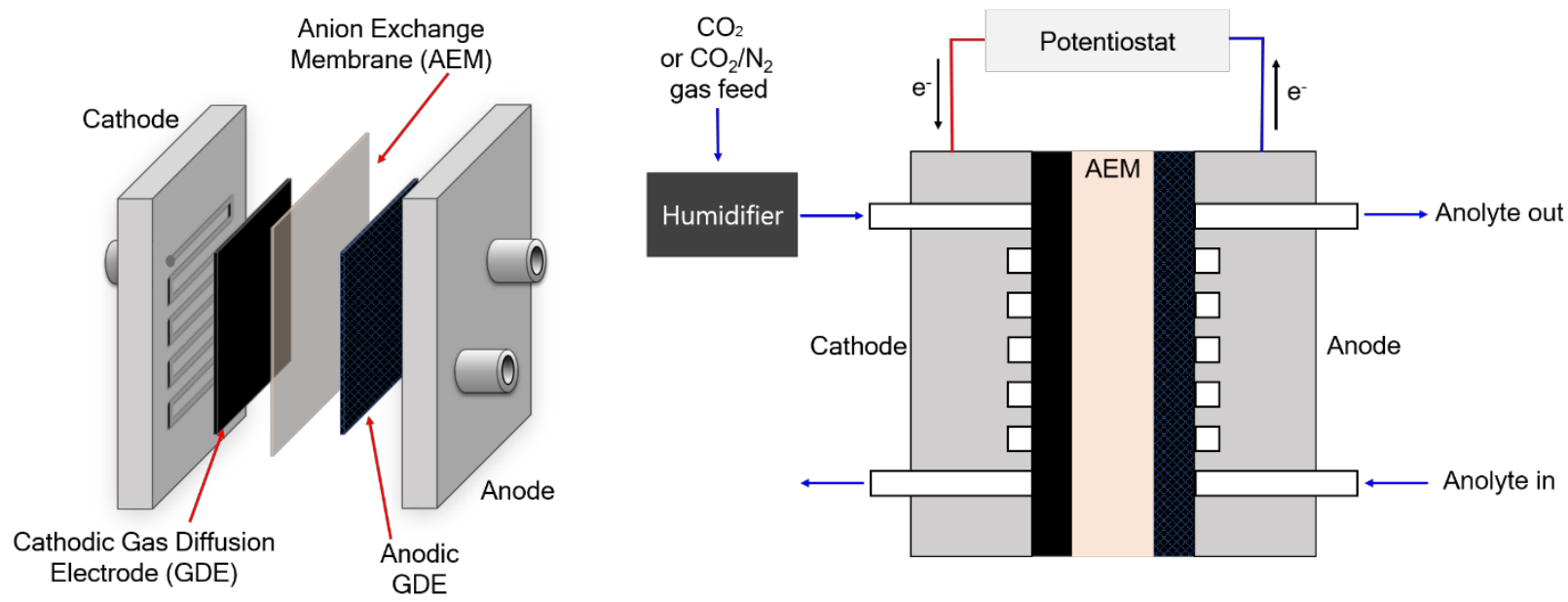

Figure S4. Schematic illustrations of a zero-gap MEA electrolyzer. 

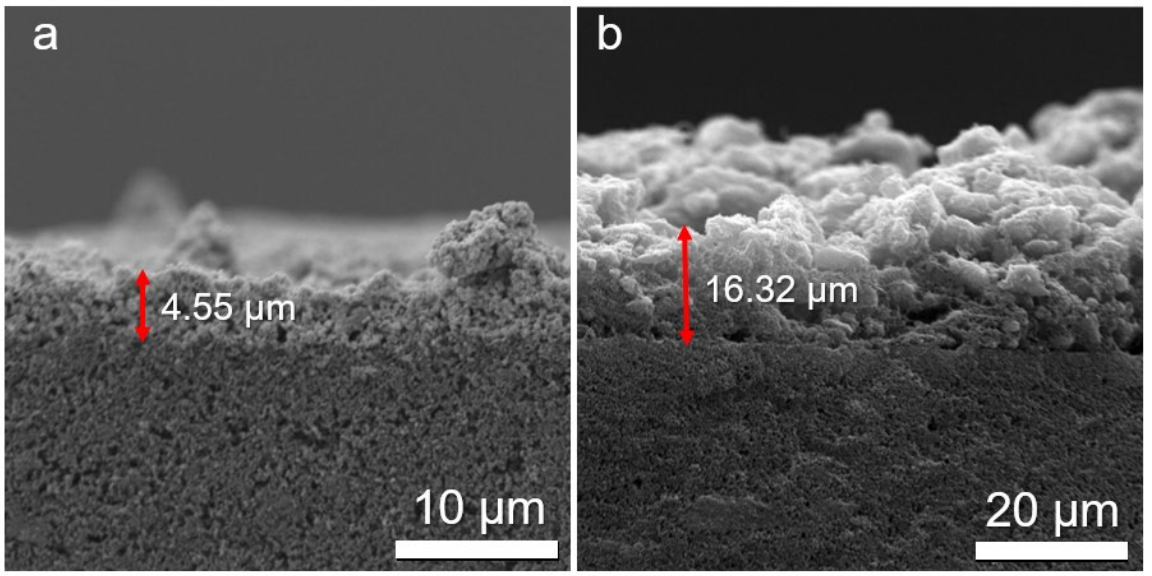

Figure S5. Cross sectional SEM images of (a) Ag nanoparticles and (b) Ni-N/C electrodes in which each $1 \mathrm{mg} \mathrm{cm}^{-2}$ of catalyst was sprayed on the carbon paper.
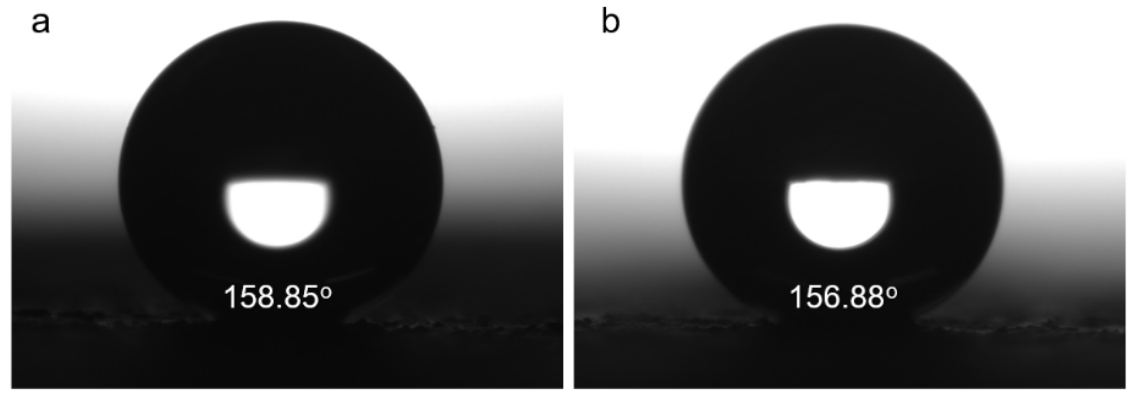

Figure S6. The images of water contact angle on the surface of (a) Ni-N/C and (b) Ag electrodes. 

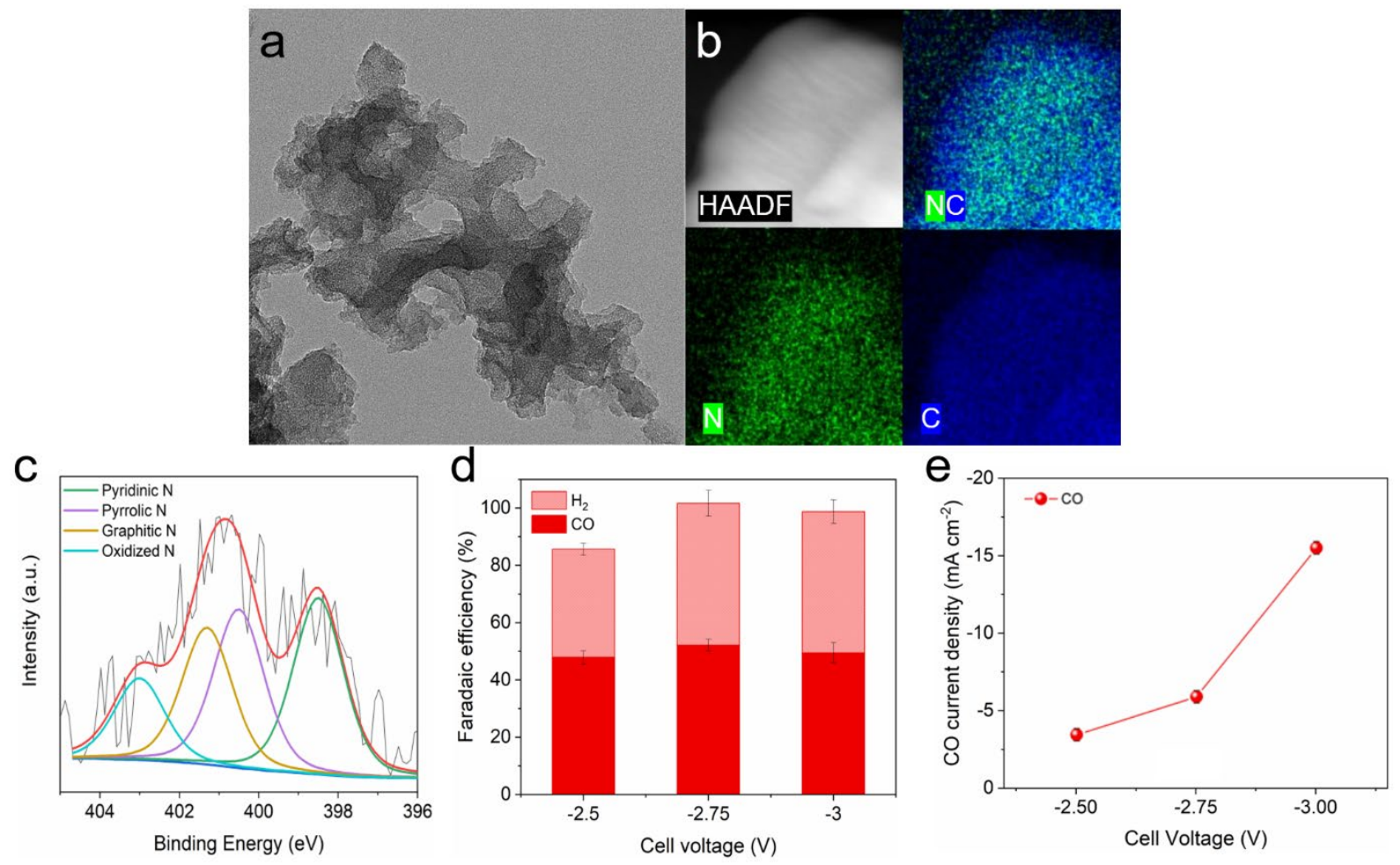

Figure S7. Characterization of the prepared N/C catalyst. (a) TEM image, (b) EDS mapping image, and (c) XPS-N $\mathrm{N}_{1 \mathrm{~s}}$ spectrum of $\mathrm{N} / \mathrm{C}$. Electrochemical $\mathrm{CO}_{2} \mathrm{R}$ performance of $\mathrm{N} / \mathrm{C}$ in the MEA electrolyzer. (d) $\mathrm{FE}_{\mathrm{CO}}$ (bottom) and $\mathrm{FE}_{\mathrm{H} 2}$ (top), and (e) $\mathrm{CO}$ partial current density under various cell voltages. 

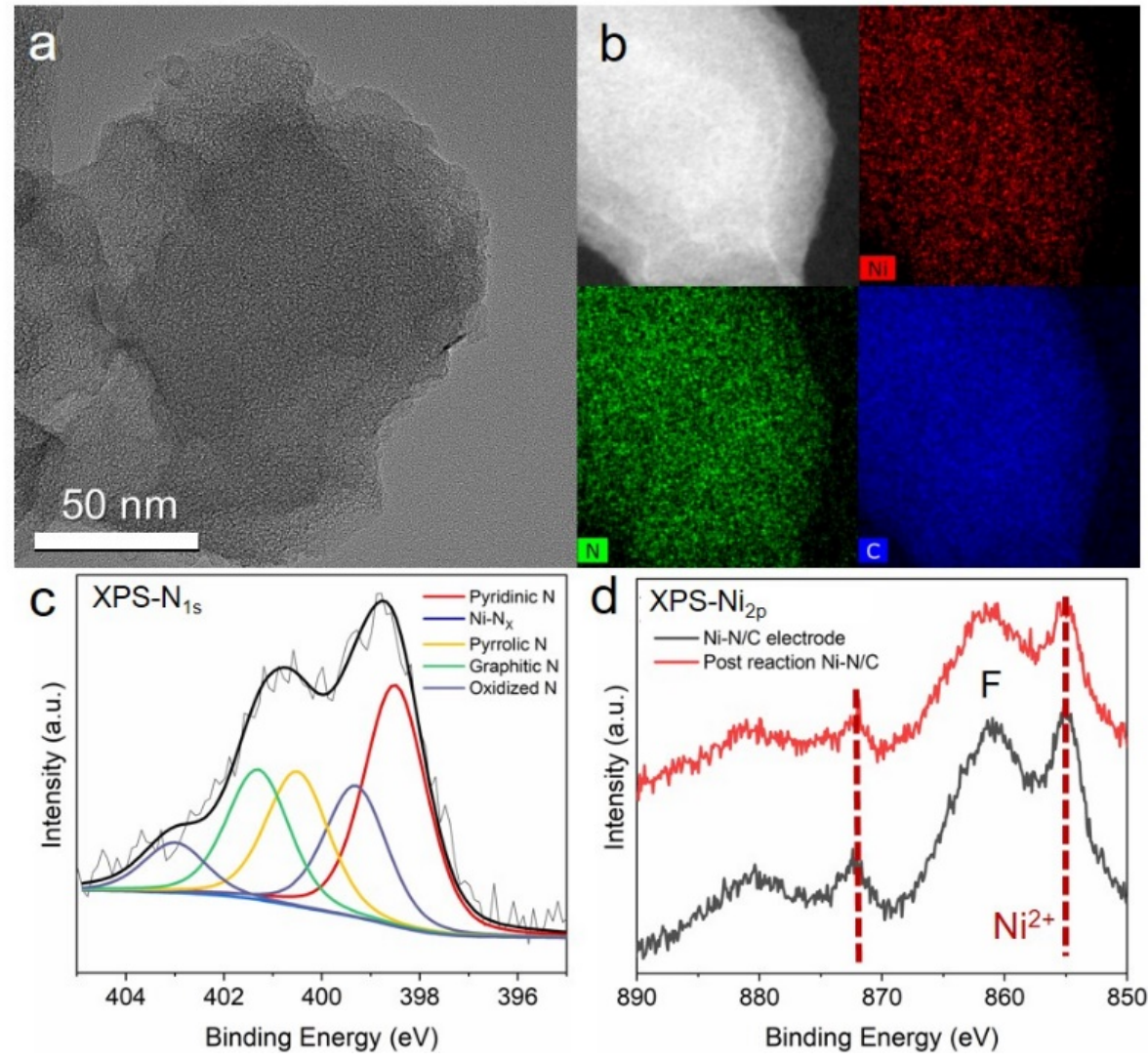

Figure S8. Characterization of the post- $\mathrm{CO}_{2} \mathrm{R}$ Ni-N/C catalyst. (a) TEM image, (b) EDS mapping image, (c) XPS-N $\mathrm{N}_{1 \mathrm{~s}}$ spectrum, (d) XPS-Ni ${ }_{2 p}$ spectrum of pre-reaction Ni-N/C (black) and postreaction $\mathrm{Ni}-\mathrm{N} / \mathrm{C}$ (red). 

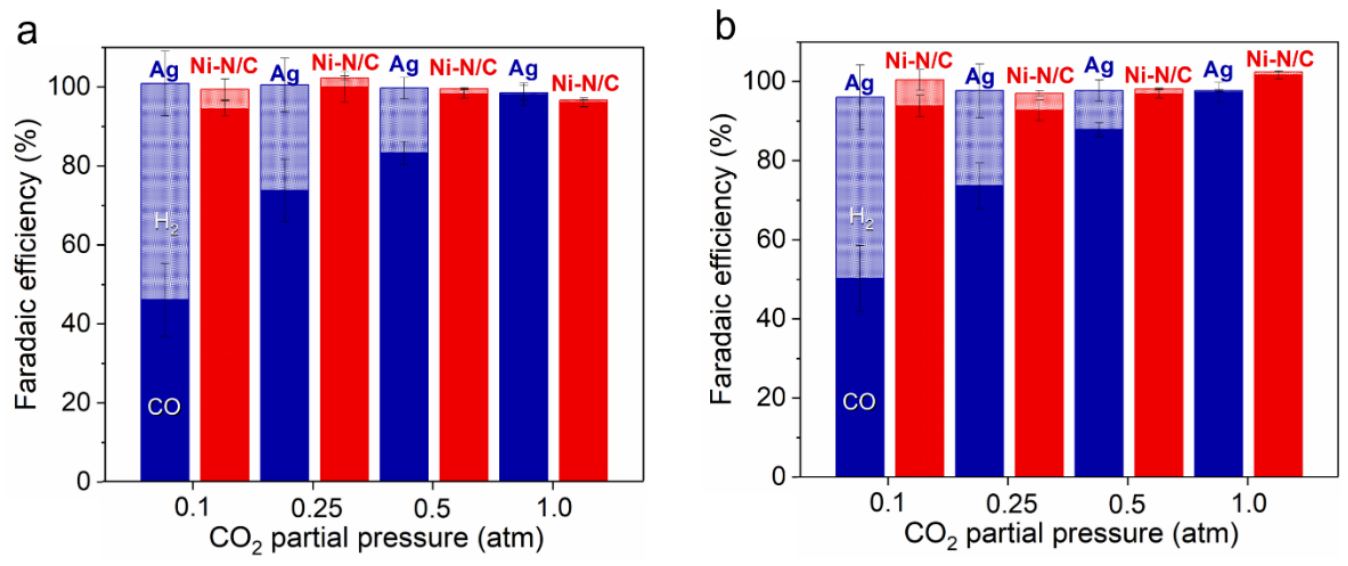

Figure S9. Electrochemical $\mathrm{CO}_{2} \mathrm{R}$ performance of $\mathrm{Ag}$ nanoparticles (blue) and Ni-N/C (red) electrodes in the MEA electrolyzer. $\mathrm{CO}$ Faradaic efficiency (bottom bar) and $\mathrm{H}_{2}$ Faradaic efficiency (top bar) of $\mathrm{Ag}$ nanoparticles and Ni-N/C under various $P_{\mathrm{CO} 2}$ conditions at (a) -2.5 and (b) $-2.75 \mathrm{~V}$ of cell voltages with a constant flow rate of $200 \mathrm{~mL} \mathrm{~min}^{-1}$. 

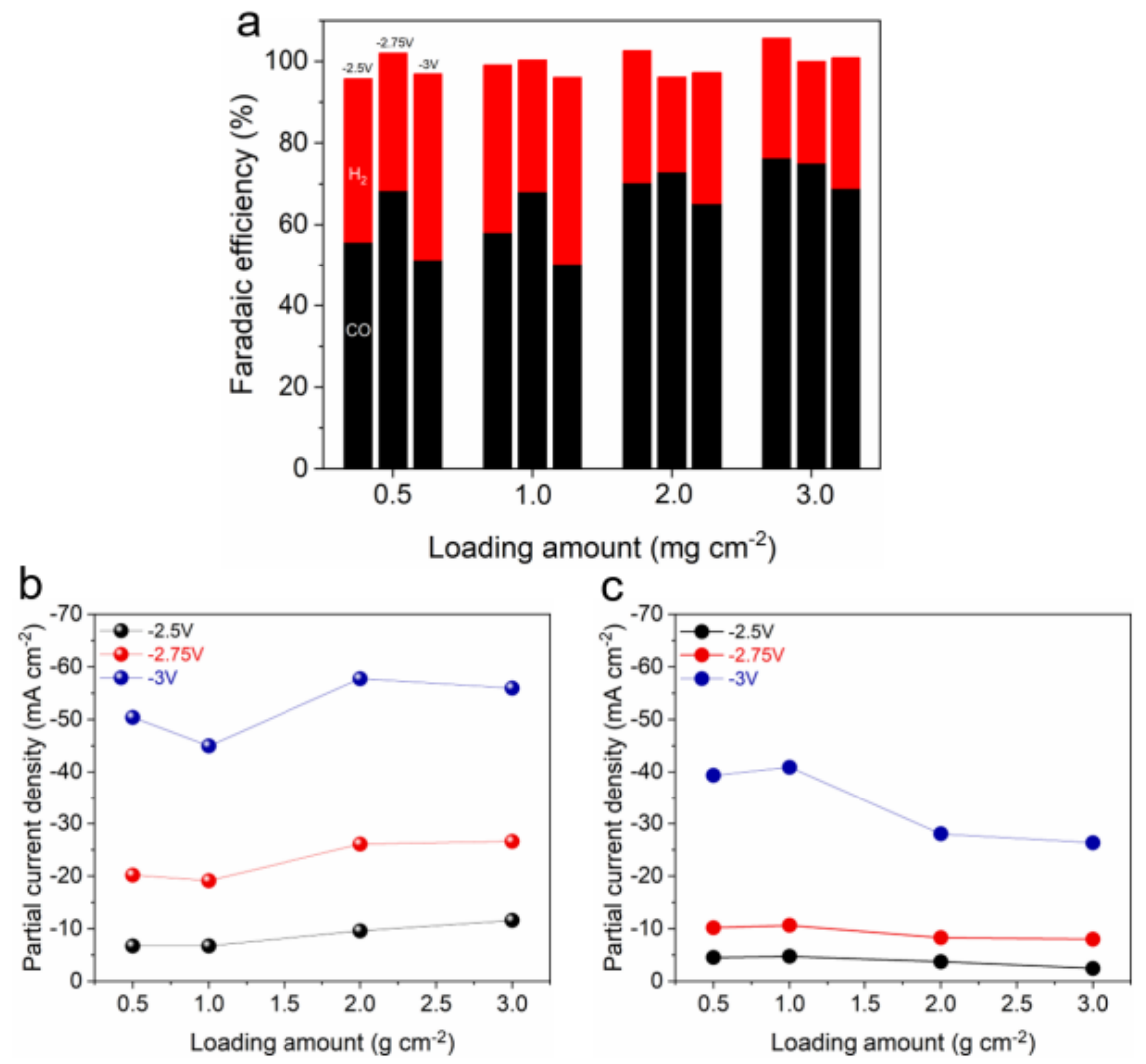

Figure S10. $\mathrm{CO}_{2} \mathrm{R}$ performance of $\mathrm{Ag}$ electrodes with various $\mathrm{Ag}$ loading amounts from 0.5 to 3 . $0 \mathrm{mg} \mathrm{cm}^{-2}$. (a) Faradaic efficiency of $\mathrm{CO}$ (black) and $\mathrm{H}_{2}$ (red), (b) $\mathrm{CO}$ partial current density and (c) $\mathrm{H}_{2}$ partial current density of various $\mathrm{Ag}$ electrodes at $0.1 \mathrm{~atm}$ of $P_{\mathrm{CO} 2}$ condition. 

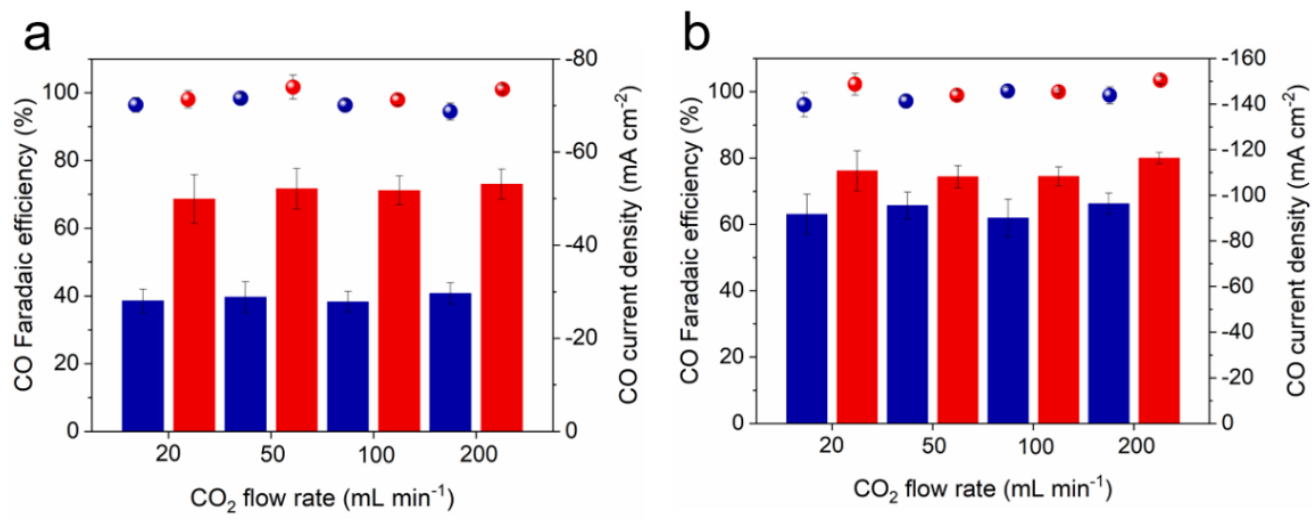

Figure S11. Electrochemical performance of Ag nanoparticle (blue) and Ni-N/C (red) with various $\mathrm{CO}_{2}$ flow rates from 20 to $200 \mathrm{~mL} \mathrm{~min}{ }^{-1}$. CO Faradaic efficiency (circle) and CO partial current density (bar) at (a) -2.5 and (b) $-2.75 \mathrm{~V}$ of cell voltages. 

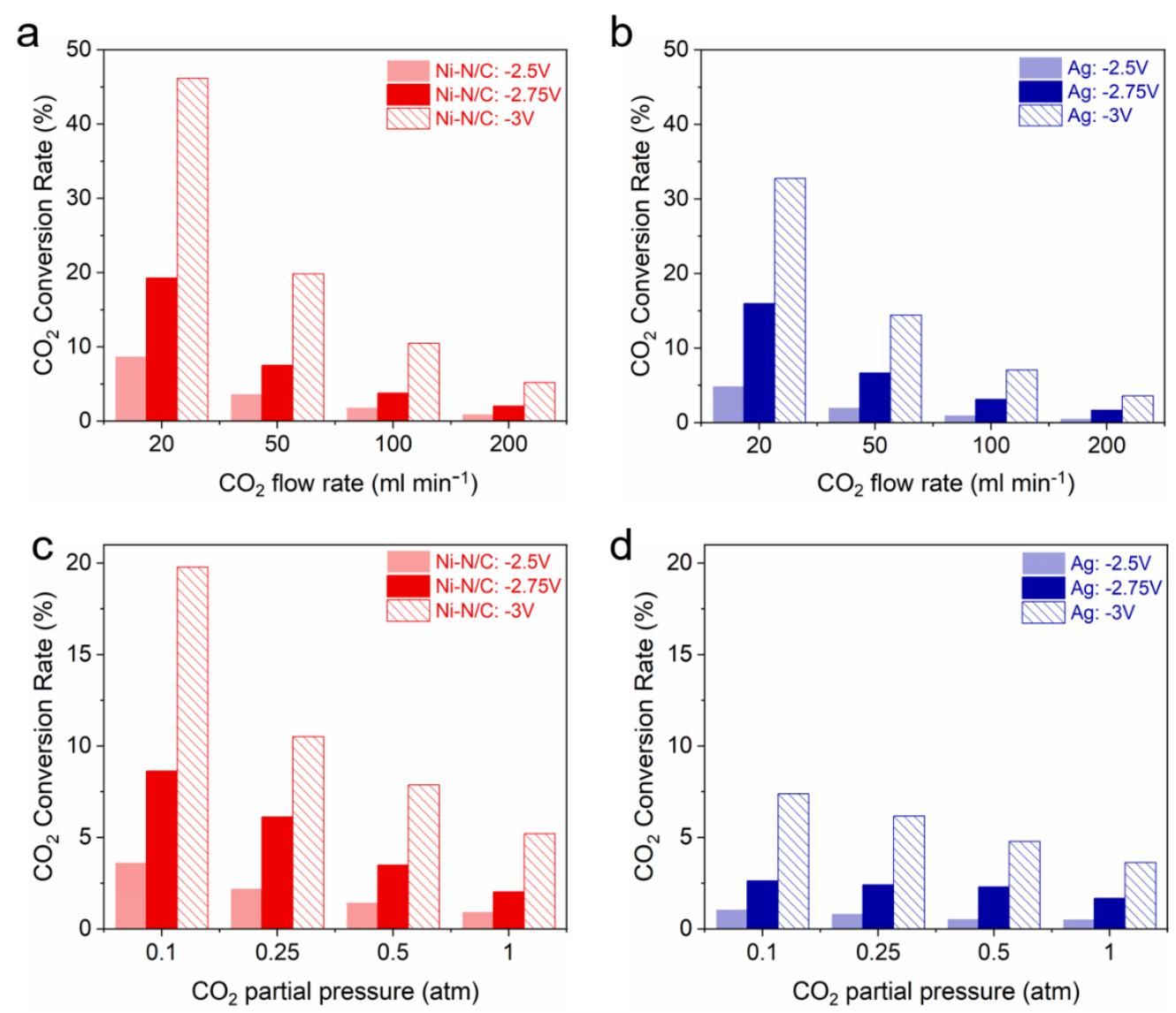

Figure S12. $\mathrm{CO}_{2}$ conversion rate under various $\mathrm{CO}_{2}$ flow rates on (a) Ni-N/C and (b) $\mathrm{Ag}$ nanoparticle electrodes during $\mathrm{CO}_{2} \mathrm{R}$ in the MEA system. $\mathrm{CO}_{2}$ conversion rate under various $P_{\mathrm{CO} 2}$ conditions on (c) Ni-N/C and (d) Ag nanoparticle electrodes during $\mathrm{CO}_{2} \mathrm{R}$ in the MEA. 

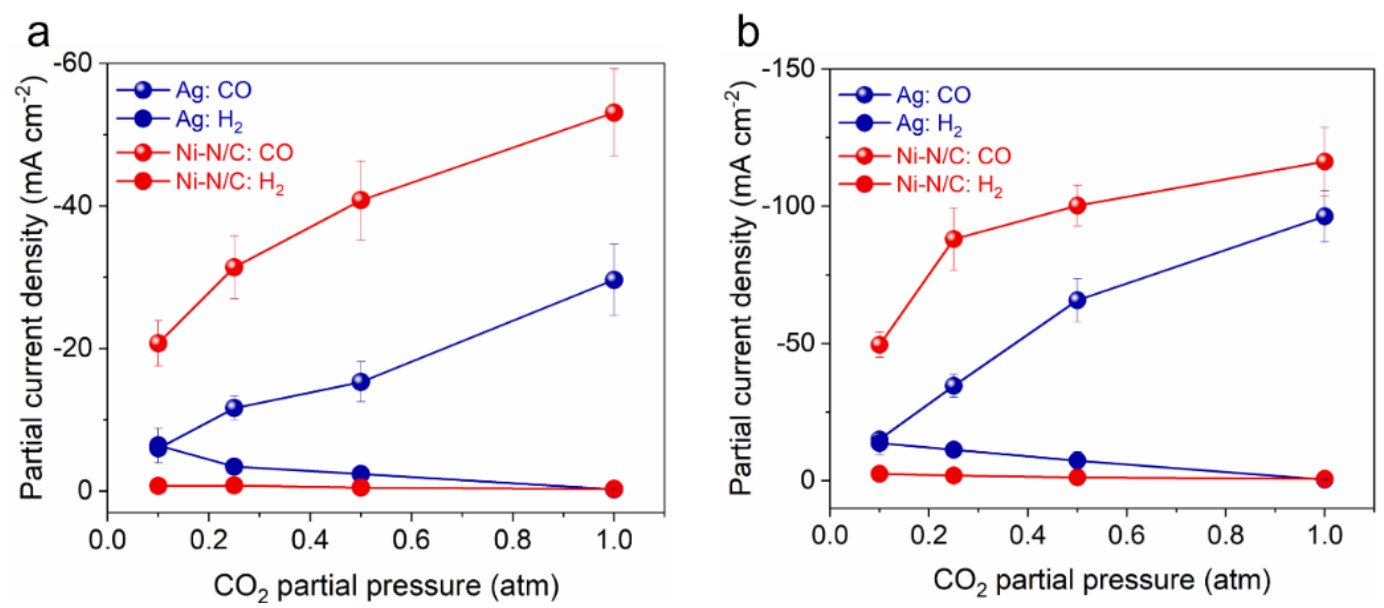

Figure S13. $\mathrm{CO}\left(3 \mathrm{D}\right.$ circle) and $\mathrm{H}_{2}\left(2 \mathrm{D}\right.$ circle) partial current densities under various $P_{\mathrm{CO} 2}$ conditions at (a) $-2.5 \mathrm{~V}$ and (b) $-2.75 \mathrm{~V}$ with a constant flow rate of $200 \mathrm{~mL} \mathrm{~min}{ }^{-1} \mathrm{on} \mathrm{Ag}$ nanoparticle (blue) and Ni-N/C (red) electrodes during $\mathrm{CO}_{2} \mathrm{R}$ in the MEA electrolyzer. 

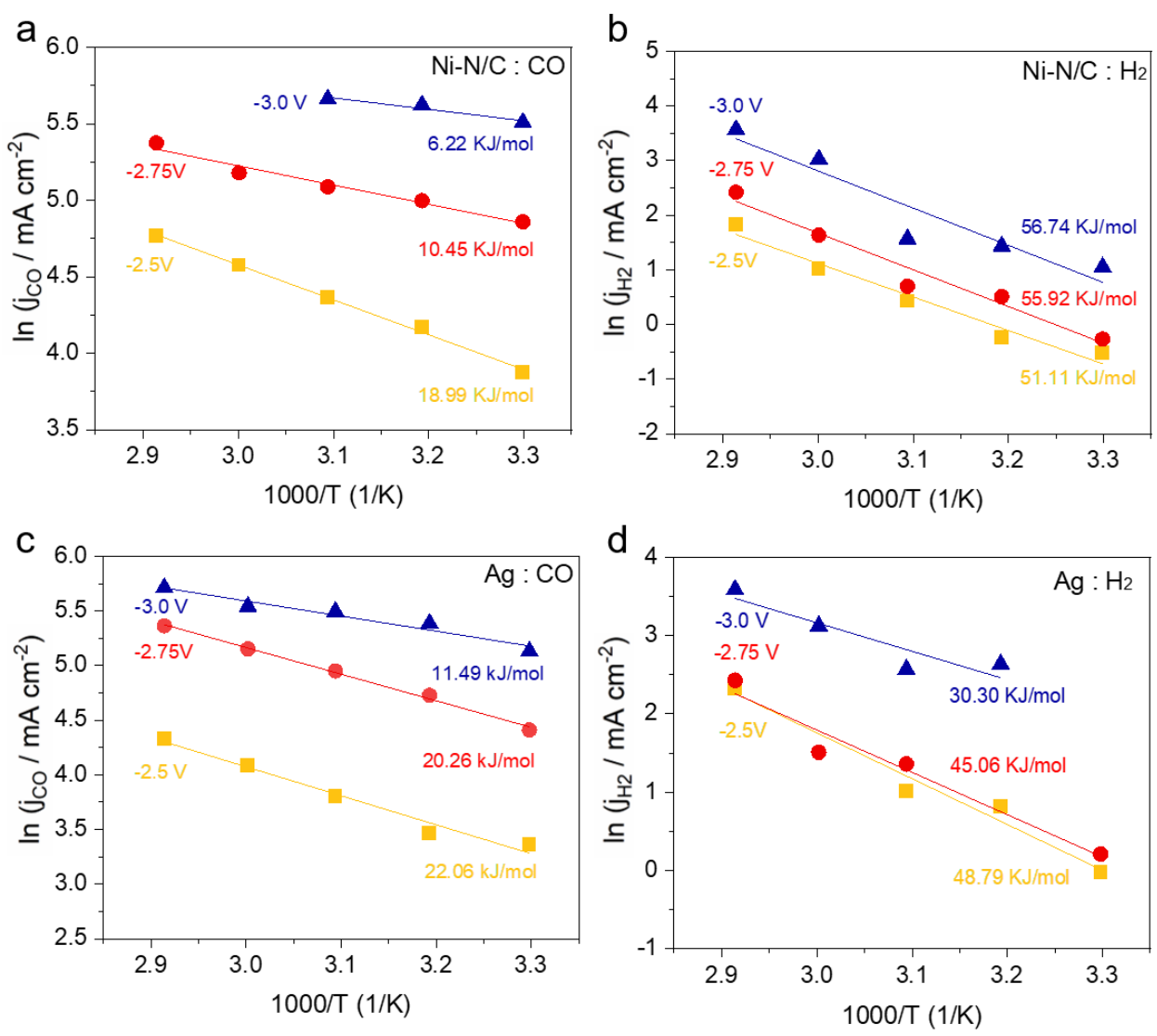

Figure S14. Activation energy ( $\left.E_{\text {act }}\right)$ of Ni-N/C for (a) $\mathrm{CO}_{2}$-to-CO and (b) HER. $E_{\text {act }}$ of $\mathrm{Ag}$ nanoparticle for (c) $\mathrm{CO}_{2}$-to-CO and (d) HER. $E_{\text {act }}$ (slope) calculated by Arrhenius plots of $\mathrm{CO}$ and $\mathrm{H}_{2}$ partial current density (at applied voltages) versus an inverse of the operating temperature. 


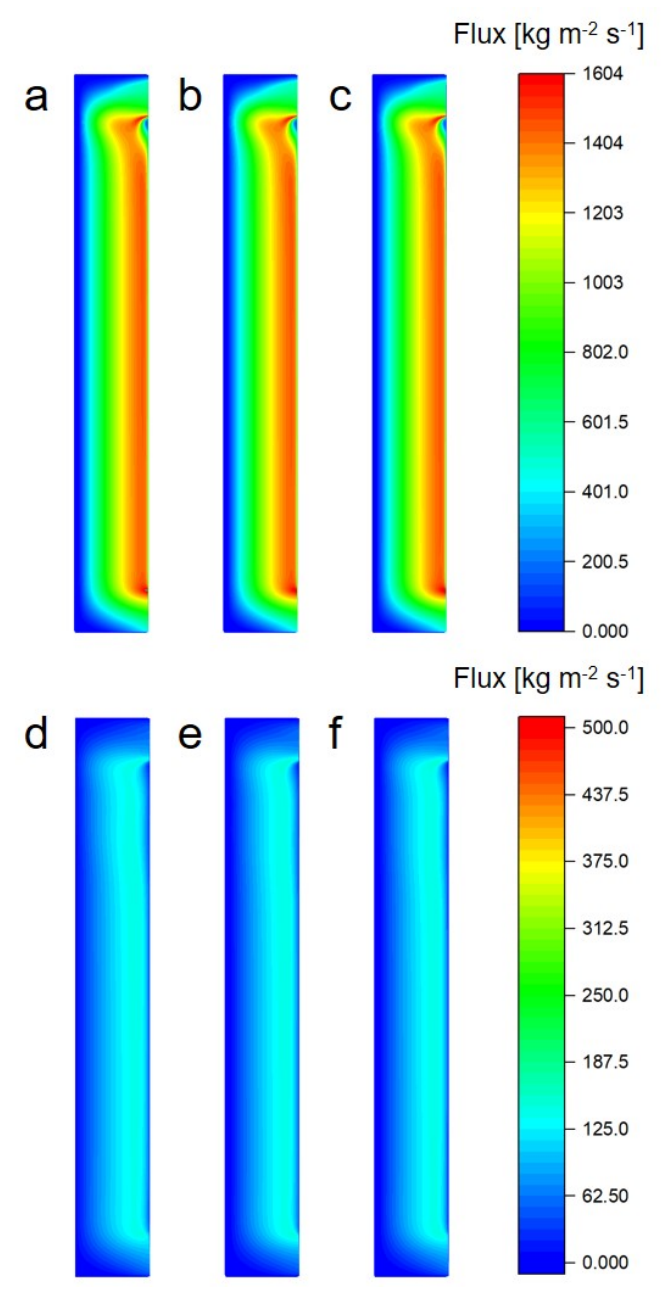

Figure S15. CFD simulations to calculate the water crossover amount from anode part to cathode part during $\mathrm{CO}_{2} \mathrm{R}$ in MEA under various combination of anolyte flow rate (i.e., 70 and $7 \mathrm{~mL} \mathrm{~min}^{-}$ ${ }^{1}$ ) and $\mathrm{CO}_{2}$ flow rate (i.e., 200, 500, and $800 \mathrm{~mL} \mathrm{~min}^{-1}$ ) conditions. Simulation results under condition of (a) $70 \mathrm{~mL} \mathrm{~min}^{-1}$ of anolyte flow and $200 \mathrm{~mL} \mathrm{~min}^{-1}$ of $\mathrm{CO}_{2}$ flow rate, (b) $70 \mathrm{~mL} \mathrm{~min}^{-1}$

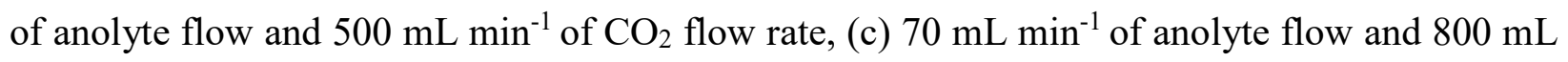

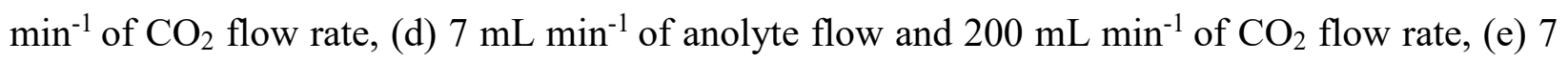
$\mathrm{mL} \mathrm{min}^{-1}$ of anolyte flow and $500 \mathrm{~mL} \mathrm{~min}^{-1}$ of $\mathrm{CO}_{2}$ flow rate, and (f) $7 \mathrm{~mL} \mathrm{~min}^{-1}$ of anolyte flow and $800 \mathrm{~mL} \mathrm{~min}^{-1}$ of $\mathrm{CO}_{2}$ flow rate. 


\section{$\underline{\text { Supplementary Table }}$}

Table S1. Comparison of $\mathrm{CO}_{2} \mathrm{R}$ performance in diluted $\mathrm{CO}_{2}$ condition.

\begin{tabular}{|c|c|c|c|c|c|c|c|c|}
\hline $\begin{array}{c}\text { Main } \\
\text { Product }\end{array}$ & $\begin{array}{c}\text { Cataly } \\
\text { st }\end{array}$ & Reactor & Electrolyte & $\begin{array}{l}P_{\mathrm{CO} 2} \\
\text { (atm) }\end{array}$ & $\begin{array}{l}\text { Cell voltage } \\
\text { (Cathode } \\
\text { potential) }\end{array}$ & $\begin{array}{c}\text { Current } \\
\text { Density } \\
\left.(\mathbf{m A ~ c m})^{-2}\right)\end{array}$ & $\begin{array}{l}\text { FE } \\
(\%)\end{array}$ & Ref. \\
\hline \multirow{5}{*}{$\mathrm{CO}$} & $\mathrm{Ni}-\mathrm{N} / \mathrm{C}$ & MEA Cell & $0.1 \mathrm{M} \mathrm{KHCO}_{3}$ & 0.1 & $-3 \mathrm{~V}$ & -113.6 & 93 & $\begin{array}{l}\text { This } \\
\text { work }\end{array}$ \\
\hline & $\mathrm{Ni}-\mathrm{N}-\mathrm{C}$ & H-type Cell & $0.5 \mathrm{M} \mathrm{KHCO}_{3}$ & 0.15 & $(-0.75 \mathrm{~V})$ & -2.9 & $>90$ & 4 \\
\hline & $\mathrm{Co}-\mathrm{N} / \mathrm{C}$ & MEA Cell & $0.5 \mathrm{M} \mathrm{KHCO}_{3}$ & 0.15 & $-3 \mathrm{~V}$ & -35 & 92 & 5 \\
\hline & $\mathrm{Ag}$ & Flow Cell & $1 \mathrm{M} \mathrm{KCl}$ & 0.1 & $-3 \mathrm{~V}$ & -11.7 & 83 & 6 \\
\hline & $\mathrm{Au}_{25}$ & Flow Cell & $1 \mathrm{M} \mathrm{KOH}$ & 0.1 & $(-0.76 \mathrm{~V})$ & $>-15$ & $>90$ & 7 \\
\hline $\mathrm{CH}_{4}$ & $\mathrm{Cu}$ & Flow Cell & $1 \mathrm{M} \mathrm{KHCO}_{3}$ & 0.75 & $(-1.42 \mathrm{~V})$ & -48 & 108 & 8 \\
\hline $\mathrm{C}_{2} \mathrm{H}_{4}$ & $\mathrm{Cu}$ & $\begin{array}{l}\text { Microfluidi } \\
\text { c Reactor }\end{array}$ & $1 \mathrm{M} \mathrm{KOH}$ & 0.5 & $(-0.93 \mathrm{~V})$ & -52 & $>30$ & 9 \\
\hline \multirow{2}{*}{$\begin{array}{c}\mathrm{C}_{2} \\
\text { products }\end{array}$} & $\mathrm{Cu}_{2} \mathrm{O}$ & Flow Cell & $1 \mathrm{M} \mathrm{KHCO}_{3}$ & 0.25 & $(-0.79 \mathrm{~V})$ & -97.9 & $\begin{array}{c}48.9 \\
4\end{array}$ & 10 \\
\hline & $\begin{array}{l}\mathrm{Cu} \text { on } \\
\mathrm{PTFE}\end{array}$ & Flow Cell & $1 \mathrm{M} \mathrm{KOH}$ & 0.15 & $-3 \mathrm{~V}$ & $>-200$ & 68 & 11 \\
\hline Formate & $\mathrm{SnS}_{\mathrm{x}}$ & Flow Cell & $1 \mathrm{M} \mathrm{KOH}$ & 0.15 & $(-0.93 \mathrm{~V})$ & -84.8 & 32.6 & 12 \\
\hline
\end{tabular}




\section{Supplementary References}

(1) Wang, R.; Sun, X.; Ould-Chikh, S.; Osadchii, D.; Bai, F.; Kapteijn, F.; Gascon, J. Metal-Organic-Framework-Mediated Nitrogen-Doped Carbon for $\mathrm{CO}_{2}$ Electrochemical Reduction. ACS Appl. Mater. Interfaces 2018, 10 (17), 14751-14758.

(2) Zhao, C.; Dai, X.; Yao, T.; Chen, W.; Wang, X.; Wang, J.; Yang, J.; Wei, S.; Wu, Y.; Li, Y. Ionic Exchange of Metal-Organic Frameworks to Access Single Nickel Sites for Efficient Electroreduction of $\mathrm{CO}_{2}$. J. Am. Chem. Soc. 2017, 139 (24), 8078-8081.

(3) Weng, L. C.; Bell, A. T.; Weber, A. Z. A systematic analysis of Cu-based membrane electrode assemblies for $\mathrm{CO}_{2}$ reduction through multiphysics simulation. Energy Environ. Sci. 2020, 13, 3592-3606.

(4) Jiao, L.; Yang, W.; Wan, G.; Zhang, R.; Zheng, X.; Zhou, H.; Yu, S. H.; Jiang, H. L. Single-Atom Electrocatalysts from Multivariate Metal-Organic Frameworks for Highly Selective Reduction of $\mathrm{CO}_{2}$ at Low Pressures. Angew. Chem., Int. Ed. 2020, 59 (46), 20589-20595.

(5) Hou, P.; Song, W.; Wang, X.; Hu, Z.; Kang, P. Well-Defined Single-Atom Cobalt Catalyst for Electrocatalytic Flue Gas $\mathrm{CO}_{2}$ Reduction. Small 2020, 16 (24), e2001896.

(6) Kim, B.; Ma, S.; Molly Jhong, H.-R.; Kenis, P. J. A. Influence of dilute feed and pH on electrochemical reduction of $\mathrm{CO}_{2}$ to $\mathrm{CO}$ on $\mathrm{Ag}$ in a continuous flow electrolyzer. Electrochim. Acta 2015, 166, 271-276.

(7) Kim, B.; Seong, H.; Song, J. T.; Kwak, K.; Song, H.; Tan, Y. C.; Park, G.; Lee, D.; Oh, J. Over a 15.9\% Solar-to-CO Conversion from Dilute $\mathrm{CO}_{2}$ Streams Catalyzed by Gold Nanoclusters Exhibiting a High $\mathrm{CO}_{2}$ Binding Affinity. ACS Energy Letters 2019, 5 (3), 749-757. 
(8) Wang, X.; Xu, A.; Li, F.; Hung, S. F.; Nam, D. H.; Gabardo, C. M.; Wang, Z.; Xu, Y.; Ozden, A.; Rasouli, A. S.; et al. Efficient Methane Electrosynthesis Enabled by Tuning Local $\mathrm{CO}_{2}$ Availability. J. Am. Chem. Soc. 2020, 142 (7), 3525-3531.

(9) Song, H.; Song, J. T.; Kim, B.; Tan, Y. C.; Oh, J. Activation of $\mathrm{C}_{2} \mathrm{H}_{4}$ reaction pathways in electrochemical $\mathrm{CO}_{2}$ reduction under low $\mathrm{CO}_{2}$ partial pressure. Appl. Catal., B 2020, 272.

(10) Tan, Y. C.; Lee, K. B.; Song, H.; Oh, J. Modulating Local $\mathrm{CO}_{2}$ Concentration as a General Strategy for Enhancing $\mathrm{C}-\mathrm{C}$ Coupling in $\mathrm{CO}_{2}$ Electroreduction. Joule 2020, 4 (5), 1104-1120.

(11) Xu, Y.; Edwards, J. P.; Zhong, J.; O’Brien, C. P.; Gabardo, C. M.; McCallum, C.; Li, J.; Dinh, C.-T.; Sargent, E. H.; Sinton, D. Oxygen-tolerant electroproduction of C2 products from simulated flue gas. Energy Environ. Sci. 2020, 13 (2), 554-561.

(12) Choi, B.-U.; Tan, Y. C.; Song, H.; Lee, K. B.; Oh, J. System Design Considerations for Enhancing Electroproduction of Formate from Simulated Flue Gas. ACS Sustainable Chem. Eng. 2021, 9 (5), 2348-2357. 